\title{
Reuse of Textile Wastewater After Treating with Combined Process of Chemical Coagulation and Electrocoagulation
}

\author{
Azhar Ali ${ }^{1 *}$, Irfan Ahmed Shaikh ${ }^{1}$, Tehreem Abid ${ }^{1}$, Faiza Samina ${ }^{2}$, Sana Islam ${ }^{1}$, \\ Anam Khalid', Nabeela Firdous ${ }^{1}$, Muhammad Talha Javed ${ }^{1}$ \\ ${ }^{1}$ College of Earth and Environmental Sciences, University of the Punjab, Lahore, Pakistan \\ ${ }^{2}$ Department of Botany, University of the Punjab, Lahore, Pakistan
}

Received: 27 October 2017

Accepted: 3 June 2018

\begin{abstract}
The basic aim of our research was to reduce water consumption in the dying process in the textile industry. This study evaluated the treatment efficiency of combined process of chemical coagulation and electrocoagulation on the synthetically produced dyes C.I. Reactive Yellow 145 and C.I Reactive Red 194. The wash-off liquor generated during the dyeing process was decolorized by adding a mixture of alum and chitosan, followed by electrocoagulation and reused for the wash-off of dyes. Fabric color was analyzed by wash fastness, rubbing and crocking experiments. The combined treatment process was proven to be very effective in decolorizing both dyes by $99.1 \%$ and $96.15 \%$. The color difference values of standard (dyed in fresh water) and batch samples for both dyes were 0.53 and 0.35 , which is within the acceptable limit $(\leq 1.0)$. The wash fastness test indicated a range of $4-5$ for both standards and batch samples. In the case of water quality parameters, a decrease in $\mathrm{pH}$ values was observed after treatment; however, an increasing trend was seen in cases of COD, TDS and EC. While these parameters do not affect the color of the fabric in dying process, this study concludes that the combined treatment of chemical and electrocoagulation is very efficient for decolorizing dye wastewater. Reuse of treated wash-off wastewater is suitable not only for reducing water consumption but also reducing wastewater generation in the textile industry. Hence this treatment option will improve overall water efficiency of the textile industry.
\end{abstract}

Keywords: wastewater treatment, coagulation, reactive dyes, textile

\section{Introduction}

Water availability is one of the global issues in the $21^{\text {st }}$ century, and people are dependent on

*e-mail: azhar.cees@pu.edu.pk

appropriate management of this valuable resource [1]. Industrialization and the rise in domestic activities, including lifestyle changes, have spurred an immense increase in the demand for water [2].

The textile industry has great importance in growing Pakistan's economy, and is considered to consume high amounts of fresh water from rivers and 
groundwater sources [3]. The textile industry is a variegated and diverse industry that has a big economic impact worldwide. As with all the pros of the textile industry, there are some very concerning cons, as it is a leading cause of environmental issues due to toxic effluents being discharged in huge amounts with different levels of turbidity, total suspended solids (TSS), total dissolved solids (TDS), COD, BOD and $\mathrm{pH}$. The industry consumes a major portion of the production of dyestuff, which is approximately or more than $60 \%$. As dye is applied, around $50 \%$ of the material is discharged into water bodies, resulting in pollution [4-6].

Textile industries grossly produce heavy amounts of harmful effluent, which can cause environmental pollution if not treated [7]. Reactive dyes are known to cause different respiratory ailments, including asthma, allergic dermatitis and different immunologic respiratory ailments [8]. Textile effluent is used for irrigation purposes as well, which can cause harm to plants and soil fertility. These effluents are discharged to water bodies, which in turn are dangerous to aquatic life [9].

Water is a very important resource in the current era of human living. Hence the reuse of this water is gaining interest not only for its importance in our lives but also for the well-being of the environment [10]. Wastewater generated from the textile industry can be treated by various methods such as biological treatments (aerobic and anaerobic degradation), advanced oxidation processes (AOP's) and physico-chemical treatments (coagulation, adsorption, electrochemical processes and membrane technology) [11].

Chemical coagulation is used to treat textile wastewater due to its effectiveness and ease of operation [12]. Electrocoagulation is also a very effective and simple process to treat textile wastewater [13]. It has been applied successfully for the treatment of restaurant water, potable water and textile wastewater (textile dyes solutions), etc. [14]. Electrocoagulation was proven to be a very effective method for the fast decolorization of textile dyes and also to attain maximum percentage removal capacity [15]. The combined process (chemical coagulation using PAC, electrocoagulation and adsorption process using pistachio nut shell ash) removed the color, chemical oxygen demand (COD) and biological oxygen demand (BOD) by $99 \%, 98 \%$ and $94.2 \%$, respectively [16].

The combination of alum sludge and chitosan not only reduced the alum sludge by $37.5 \%$, but also sludge production by $45.5 \%$. Results also proved that by chemically enhanced primary treatment (CEPT), color and total suspended solids (TSS) removal also enhanced by $85 \%$ and $95 \%$, respectively [17]. A study has shown that combined the process of chemical coagulation or electrocoagulation following the ion-exchange process to treat the textile dye effluent was used showing decolorizing reduction efficiency of $81.3 \%$, and it was proved very effective in enhancing the quality of the treated wastewater for the purpose of reuse [18]. In this paper the combined process was used to in order to get $99 \%$ efficiency.

According to Butler et al. [19], the combined treatment with chemical coagulant and electro coagulation reached $99.42 \%$ efficiency of color removal of dye from wastewater. This study depends on various parameters such as dye type, coagulant type, weight, dose, $\mathrm{pH}$ and density by using Box Behnken methodology [19].

In comparison with different treatment methods, Lin and Peng [20] state that biological treatment takes more time for overall treatment that chemical and electrocoagulation processes [20]. A study has shown that chemical and electrocoagulation treatment take 45 minutes and one hour, respectively, compared to biological treatment with 3 to 4 hours or even more [21].

The aims of the study are to:

- Analyze decolorization of synthetically produced wastewater from the wash-off process.

- Evaluate the treatment efficiency of the combined processes of chemical coagulation and electrocoagulation (EC) for synthetically produced dye-rich wastewater.

- Measure the reuse ability of treated wastewater in the dying process again and the fabric color strength compared with the standard.

\section{Materials and Methods}

\section{Preparing Synthetic Dye}

\section{Dyeing Process}

The 1\% stock solution for dyeing was prepared by adding $10 \mathrm{~g}$ of C.I Reactive Yellow 145 and C.I Reactive Red 194 to a $1000 \mathrm{ml}$ flask one by one and made them up to the mark by using distilled water. The process of dyeing was carried out using an isothermal process (see Table 1).

For both dyes, $25 \mathrm{ml}$ of stock solution and $50 \mathrm{ml}$ of water was added in the beaker to make the volume up to $75 \mathrm{ml}$. The beaker was then placed in a water bath of $60^{\circ} \mathrm{C} .6 \mathrm{~g}$ of salt and $5 \mathrm{~g}$ fabric were added in the solution and mixed. As soon as the temperature reached

Table 1. Process conditions for dyeing.

\begin{tabular}{|c|c|c|}
\hline Sr. $\#$ & Parameters & Values \\
\hline 1. & L:R & $1: 15$ \\
\hline 2. & Dye $\%$ & $5 \%$ \\
\hline 3. & Temperature $\left({ }^{\circ} \mathrm{C}\right)$ & 60 \\
\hline 4. & Salt $(\mathrm{NaCl})$ & $80 \mathrm{~g} / 1$ \\
\hline 5. & Sodium carbonate $\left(\mathrm{Na}_{2} \mathrm{CO}_{3}\right)$ & $20 \mathrm{~g} / 1$ \\
\hline 6. & Time & $45 \mathrm{mins}$ \\
\hline
\end{tabular}




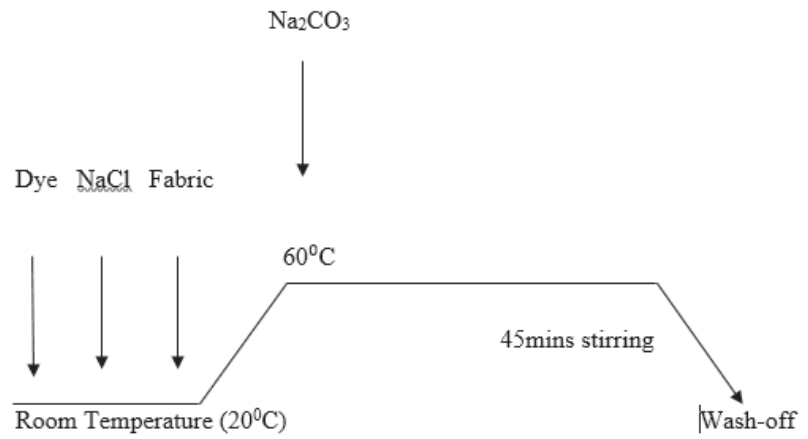

Fig. 1. Standard isothermal dyeing.

$60^{\circ} \mathrm{C}, 1.5 \mathrm{~g}$ of $\mathrm{Na}_{2} \mathrm{CO}_{3}$ was added to the solution while being continuously stirred for 45 minutes to avoid uneven dyeing (Fig. 1) [22].

\section{Wash-off Process}

After dyeing, the fabric was subjected to the wash-off process by pressing it to remove unfixed dye. The process of wash-off was performed by taking a 1:10 liquor ratio. It was carried out in six different steps. Each step was completed in five minutes (Table 2). First of all, the dyed fabric was rinsed under tap water. For the other five steps five beakers were taken with $50 \mathrm{ml}$ of water in each. For the second step of wash-off, called neutralization, two to three drops of acetic acid were added to the beaker and the fabric was continuously stirred for five minutes. In the third step the temperature of the beaker was set to $50^{\circ} \mathrm{C}$ and the fabric was added to it and stirred for five minutes. In the next step the water in the beaker was maintained at $80^{\circ} \mathrm{C}$ and two to three drops of soaping agent were added. Fabric was then added and stirred continuously. In the fifth step, the temperature of the water in the beaker was again set to $50^{\circ} \mathrm{C}$ and fabric was again stirred continuously for five minutes. In the last and sixth step, fabric was added in the beaker having water at room temperature and stirred again. Fabric dyed in fresh water was termed as standard. So in the overall process, an average of 5 samples were taken for each dye wastewater wash-off, and treatment was applied for 2 mixed samples.

Table 2. Steps of the wash-off process.

\begin{tabular}{|c|c|}
\hline Steps & Operation \\
\hline 1. & Cold rinse $\left(20^{\circ} \mathrm{C}\right)$ \\
\hline 2. & Neutralization $\left(20^{\circ} \mathrm{C}\right)$ \\
\hline 3. & Warm wash $\left(50^{\circ} \mathrm{C}\right)$ \\
\hline 4. & Hot wash $\left(80^{\circ} \mathrm{C}\right)$ \\
\hline 5. & Warm wash $\left(50^{\circ} \mathrm{C}\right)$ \\
\hline 6. & Cold rinse $\left(20^{\circ} \mathrm{C}\right)$ \\
\hline
\end{tabular}

\section{Treatment Construction and Experiments}

\section{Coagulation and Electrocoagulation}

After all the steps of wash-off process were carried out, the spent wash-off liquor $(250 \mathrm{ml})$ of the last five steps was taken in a beaker. For the spent wash-off liquor of the C.I Reactive Yellow 145 and C.I Reactive Red 194, the $\mathrm{pH}$ was kept basic in order to avoid the acid cost. The mixture of alum $(0.12 \mathrm{~g} / 250 \mathrm{ml})$ and chitosan $(0.25 \mathrm{~g} / 250 \mathrm{ml})$ was then added in them and stirred with the help of magnetic stirrer for 3 minutes. After that they were left for one hour at room temperature. After one hour the mixture was filtered using Whatman filter paper. After that the process of electrocoagulation (using iron and aluminum electrodes) was applied to the filtered mixture for 1 minute in order to completely decolorize it, and then filtered using filter paper. Reaction time also affects the treatment efficiency of the electrocoagulation process [23]. A $0.75 \mathrm{amp}$ current was used as a direct current for electrocoagulation. This filtered mixture then reused in the next wash-off and the dyed fabric was called batch sample.

\section{Measurement and Analysis}

Determining color removal (\%), water quality parameters, color differences $\left(\Delta \mathrm{L}^{*}, \Delta \mathrm{a}^{*}, \Delta \mathrm{b}^{*}, \Delta \mathrm{C}^{*}, \Delta \mathrm{H}^{*}\right.$ and $\Delta \mathrm{E}^{*}$ ), wash fastness (testing of wash fastness was performed as per International Standards (ISO 105; $\mathrm{C} 06 / \mathrm{C} 2 \mathrm{~S}$ wash test at $50^{\circ} \mathrm{C}$ ) and this test was completed using an SDC multi-fiber acting as adjacent fiber, rubbing and crooking test (color shifting from test fabric to fabric is called rubbing/crooking). If there is high color transfer the fabric has high crocking, and utilizing AATCC 8 method a standard white cotton fabric is used to rub with the fabric to be tested, which was included in analytical measurement [24].

\section{Color Measurement}

This comprises the color matching and color differences $\left(\Delta \mathrm{L}^{*}, \Delta \mathrm{a}^{*}, \Delta \mathrm{b}^{*}, \Delta \mathrm{C}^{*}, \Delta \mathrm{H}^{*}\right.$ and $\left.\Delta \mathrm{E}^{*}\right)$ between

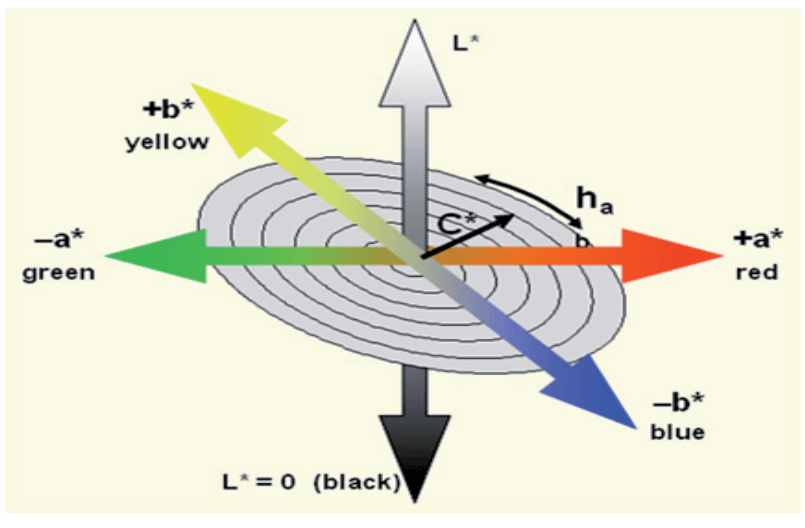

Fig. 2. CIE LAB color scale. 
the standard and batch sample fabrics [25, 21]. A uniform color scale shown in Fig. 2 called CIELAB color scale was used. $L^{*}$ describes the depth of the dyed samples. Its maximum is 100 , which describes the perfect reflecting diffuser, and the minimum is 0 , which reflects black. The positive and negative value of $a^{*}$ shows the red and green shade, respectively. The same in the case of $b^{*}$, with its positive and negative values showing the yellow and blue shade respectively. A difference in the chrome of sample and standard is called $\Delta \mathrm{C}^{*}$. It is measured by the value of $\mathrm{a}^{*}$ and $\mathrm{b}^{*}$. $\Delta \mathrm{E}^{*}$ is the color difference and is calculated by $\mathrm{L}^{*}, \mathrm{a}^{*}$ and $b^{*}$ of standard and batch sample [26].

The total color difference is calculated by the following equation:

$$
\Delta \mathrm{E}^{*}=\left[\Delta \mathrm{L}^{* 2}+\Delta \mathrm{a}^{* 2}+\Delta \mathrm{b}^{* 2}\right]^{1 / 2}
$$

\section{Results and Discussion}

\section{Estimation of Color Removal (\%)}

After the treatment of chemical coagulation, the trend of \% color removal was $95 \%$ and $86.15 \%$ for C.I Reactive Yellow 145 and C.I Reactive Red 194, respectively, whereas the combined treatment of both processes showed $99.1 \%$ and $96.15 \%$ color removal for the dyes, respectively. This implied that a combination of both processes did great work in decolorizing the wastewater for both dyes, and excellent results were obtained. A study conducted to treat the textile wastewater by applying electrocoagulation resulted in nearly complete decolorization, i.e., 92.3\% [14], while another study using Box Behnken methodology gave an efficiency of 99.4\% [19]. EC treatment was applied to remove the orange dye from the solution and the result was $98.3 \%$ [27]. It was observed that $99.9 \%$ decolorization was achieved by applying combined chemical coagulation, electrocoagulation and adsorption processes [16].

\section{Water Quality Parameters}

Different water quality parameters such as $\mathrm{pH}$, conductivity, total dissolved solids (TDS) and chemical oxygen demand (COD) were observed before and after treatment of wastewater to find whether it was fit for reuse or recycle again in the dying process (Tables 3-4). Except for $\mathrm{pH}$, all the parameters showed an increasing trend for the treated wastewater. But this increasing trend did not affect the dyeing quality of fabric, hence they were negligible at that time. Research conducted to treat the textile wastewater and reuse it by the electrochemical process also experienced an increase in the TDS values after treatment, but it was concluded that this parameter did not affect the dyeing process and was ignored in this study [28].
Table 3. Values of water quality parameters of wastewater (before and after treatment) of C.I Reactive Yellow 145.

\begin{tabular}{|c|c|c|c|}
\hline Sr. \# & Parameters & Before treatment & After treatment \\
\hline 1. & $\mathrm{pH}$ & 8.7 & 7.9 \\
\hline 2. & Temperature & $20.5^{\circ} \mathrm{C}$ & $25.2^{\circ} \mathrm{C}$ \\
\hline 3. & TDS & $44 \mathrm{ppm}$ & $162 \mathrm{ppm}$ \\
\hline 4. & Conductivity & $643 \mathrm{~s} / \mathrm{m}$ & $910 \mathrm{~s} / \mathrm{m}$ \\
\hline 5. & COD & $384 \mathrm{ppm}$ & $416 \mathrm{ppm}$ \\
\hline
\end{tabular}

Table 4. Values of water quality parameters of wastewater (before and after treatment) of C.I Reactive Red 194.

\begin{tabular}{|c|c|c|c|}
\hline Sr. \# & Parameters & Before treatment & After treatment \\
\hline 1. & $\mathrm{pH}$ & 8.3 & 5.3 \\
\hline 2. & Temperature & $20.8^{\circ} \mathrm{C}$ & $25.7^{\circ} \mathrm{C}$ \\
\hline 3. & TDS & $62 \mathrm{ppm}$ & $220 \mathrm{ppm}$ \\
\hline 4. & Conductivity & $634 \mathrm{~s} / \mathrm{m}$ & $810 \mathrm{~s} / \mathrm{m}$ \\
\hline 5. & COD & $352 \mathrm{ppm}$ & $448 \mathrm{ppm}$ \\
\hline
\end{tabular}

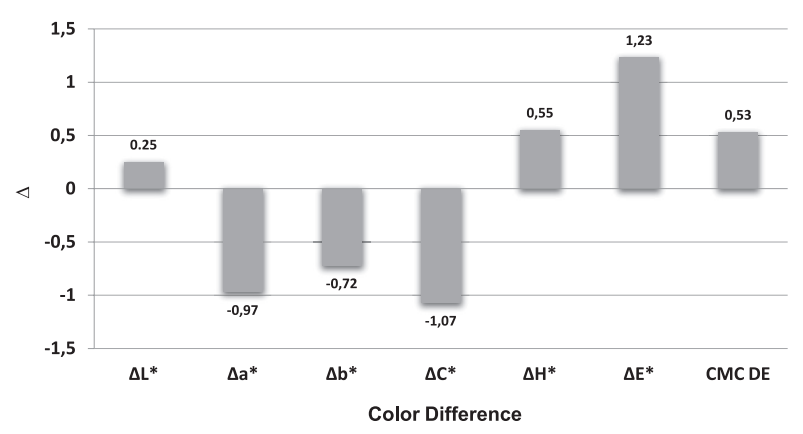

Fig. 3. Values of color differences between standard and sample fabrics dyed with C.I Reactive Yellow 145.

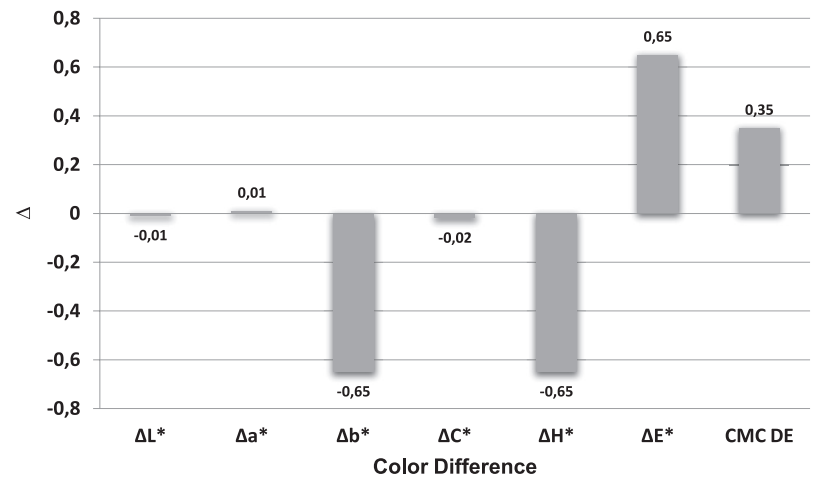

Fig. 4. Values of color differences between standard and sample fabrics dyed with C.I Reactive Red 194. 
Table 5. Wash fastness values of fabric (standard and sample) dyed with C.I Reactive Yellow 145 and C.I Reactive Red 194.

\begin{tabular}{|c|c|c|c|c|c|c|c|c|}
\hline Sr.\# & Fabric & $\begin{array}{c}\text { Cellulose } \\
\text { acetate }\end{array}$ & $\begin{array}{c}\text { Un-mercerized } \\
\text { Cotton }\end{array}$ & $\begin{array}{c}\text { Nylon } \\
6.6\end{array}$ & $\begin{array}{c}\text { Polyester } \\
\text { terylene }\end{array}$ & $\begin{array}{c}\text { Acrylic } \\
\text { (courtelle) }\end{array}$ & $\begin{array}{c}\text { Wool } \\
\text { worsted }\end{array}$ & Crocking \\
\hline 1. & $\begin{array}{c}\text { C.I Yellow } \\
145 \text { (standard) }\end{array}$ & 5 & 4.5 & 5 & 5 & 5 & 4.5 & $\begin{array}{c}\text { DRY 4.5 } \\
\text { WET 2 }\end{array}$ \\
\hline 2. & $\begin{array}{c}\text { C.I Yellow } \\
145 \text { (batch) }\end{array}$ & 5 & 4.5 & 5 & 5 & 5 & 4.5 & $\begin{array}{c}\text { DRY 4.5 } \\
\text { WET 2 }\end{array}$ \\
\hline 3. & $\begin{array}{c}\text { C.I Red194 } \\
\text { (standard) }\end{array}$ & 5 & 4 & 5 & 5 & 5 & 4.5 & $\begin{array}{c}\text { DRY 4.5 } \\
\text { WET 3 }\end{array}$ \\
\hline 4. & $\begin{array}{c}\text { C.I Red194 } \\
\text { (batch) }\end{array}$ & 5 & 4 & 5 & 5 & 5 & 4.5 & $\begin{array}{c}\text { DRY 4.5 } \\
\text { WET 3 }\end{array}$ \\
\hline
\end{tabular}

\section{Color Measurement}

The sample fabrics after wash-off were subjected to CIELAB test. With the help of this test, the color difference values between the standard and batch sample fabric were taken and compared (Figs 3-4).

In Fig. 3, $\Delta \mathrm{L}^{*}$ value of C.I Reactive Yellow 145 is positive, which shows that the sample fabric is lighter than the standard fabric. $\Delta \mathrm{a}^{*}, \Delta \mathrm{b}^{*}$ and $\Delta \mathrm{C}^{*}$ values are negative, which indicates that the sample/batch is greener, bluer and duller than the standard, whereas $\mathrm{CMC} \Delta \mathrm{E}$ value is 0.53 , which is within the acceptable limit i.e. $\leq 1.0$ [29].

This implies that the total color difference between the standard and sample fabric is acceptable and the result is good. In Fig. 4 the $\Delta \mathrm{L}^{*}$ value of C.I Reactive Red 194 is negative, which indicates that the sample fabric is darker than the standard fabric. $\Delta \mathrm{a}^{*}$ value is positive while $\Delta \mathrm{b}^{*}$ and $\Delta \mathrm{C}^{*}$ values are negative, which shows that the sample is redder, bluer and duller than the standard, whereas $\mathrm{CMC} \Delta \mathrm{E}$ value is 0.35 , which is within the acceptable limit. This implies that the total color difference between the standard and sample fabric is minimum and the result is good.

\section{Wash Fastness, Rubbin/Crocking Measurements}

Wash fastness, rubbing and crocking tests of all the standard and sample fabrics was conducted at $50^{\circ} \mathrm{C}$ (Table 5).

For C.I Reactive Yellow 145 and Red 194, the resultant wash fastness values of cotton fabric for both standard and sample is 4.5 and 4, respectively, which means they are of the same shade and close to the standard value, i.e., $5[22,30,31]$. The results are depicted under the range. This implies that the result is very good. Also, the dry and wet crocking values for both dyes showed no difference between standard and sample fabric, which indicated that dyeing quality of fabrics are good.

\section{Conclusions}

This study was designed to evaluate the efficiency of the combined process of chemical coagulation and electrocoagulation (EC) for decolorizing and reusing the spent wash-off liquor from the cotton-dyeing process containing dyes, i.e., C.I Reactive Yellow 145 and C.I Reactive Red 194. The efficiency of the combined process for the removal of dyes was determined by some operational parameters such as $\mathrm{pH}$, treatment time, coagulant dose and concentration of dye. It was observed that this process takes less time and provides economic benefits. This process effectively decolorized the C.I Reactive Yellow 145 and C.I Reactive Red 194 by $99.1 \%$ and $96.15 \%$, respectively. Quality of dyeing was also assessed for both the standard and batch sample fabrics. For C.I Reactive Yellow 145 and C.I Reactive Red 194 the total color difference observed was 0.53 and 0.35 , respectively, which was within the acceptable limit $\leq 1.0$, and is a clear indication that dyeing can be effectively done by reusing wastewater following the decolorization process.

\section{Conflict of Interest}

The authors declare no conflict of interest.

\section{References}

1. MUTIU K.A., MOHAMMED S.J., SULEYMAN A.M., MA'AN F.R.A., DZUN N.J. Zero liquid discharge and water conservation through water reclamation \& reuse of biotreated palm oil mill effluent: a review. Int. J. Acad. Res. 5 (4), 169, 2013.

2. COLE R.J. Changing context for environmental knowledge. Build. Res. Info. 32 (2), 91, 2004.

3. YASEEN M., AZIZ M.Z., JAFAR A.A., NAVEED M., SALEEM M. Use of textile waste water along with liquid NPK fertilizer for production of wheat on saline sodic soils. Int. J. Phytoremediation. 18 (5), 502, 2016.

4. TURGAY O., ERSOZ G., ATALAY S., FORSS J., WELANDER U. The treatment of azo dyes found in 
textile industry wastewater by anaerobic biological method and chemical oxidation. Sep. Purif. Technol. 79 (1), 26, 2011.

5. MORALI E.K. Ozonation of a denim producing textile industry wastewater-process optimization. Doctoral dissertation, Middle East Technical University, 2007.

6. LEE C.S., ROBINSON J., CHONG M.F. A review on application of flocculants in wastewater treatment. Proc. Saf. Environ. 92 (6), 489, 2014.

7. MORSHED M.N., AL AZAD S., ALAM M.A. M., SHAUN B.B., DEB H. An instigation to green manufacturing: Characterization and analytical analysis of textile wastewater for physico-chemical and organic pollution indicators. Amer. J. Environ. Sci. Tech. 1 (1), 11, 2016.

8. KLEMOLA K., PEARSON J. LINDSTROM-SEPPA P. Evaluating the toxicity of reactive dyes and dyed fabrics with the HaCaT cytotoxicity test. Autex Res J. 7 (3) 217, 2007.

9. CHOWDHURY M., MOSTAFA M.G., BISWAS T.K., MANDAL A., SAHA A.K. Characterization of the effluents from leather processing industries. Environmental Processes. 2 (1), 173, 2015.

10. LU X., LIU L., LIU R., CHEN J. Textile wastewater reuse as an alternative water source for dyeing and finishingprocesses:a case study. Desalination. 258 (1), 229, 2010.

11. SALAMEH W.K.B. Treatment of olive mill wastewater by ozonation and electrocoagulation processes. Civil Environ. Res. 7 (2), 80, 2015.

12. KHOUNI I., MARROT B., MOULIN P. AMAR R.B. Decolourization of the reconstituted textile effluent by different process treatments: Enzymatic catalysis, coagulation/flocculation and nanofiltration processes. Desalination. 268 (1), 27, 2011.

13. MOLLAH M.Y.A., SCHENNACH R., PARGA J.R. COCKE D.L. Electrocoagulation (EC) - science and applications. J. Hazard. Mater. 84 (1), 29, 2001.

14. KOBYA M., DEMIRBAS E., CAN O.T., BAYRAMOGLU M. Treatment of levafix orange textile dye solution by electrocoagulation. J. Hazard. Mater. 132 (2), 183, 2006.

15. TAHIR H., RAUF A. The application of electrocoagulation process for the removal of tartrazine dye from simulated waste water system. Int. J. Environ. Sci. Manag.Eng. Res. 3, 18, 2014

16. BAZRAFSHAN E., ALIPOUR M.R., MAHVI A.H. Textile wastewater treatment by application of combined chemical coagulation, electrocoagulation, and adsorption processes. Desalin. Water. Treat. 57 (20) 9203, 2016.

17. ASIF M.B., MAJEED N., IFTEKHAR S., HABIB R., FIDA S., TABRAIZ S. Chemically enhanced primary treatment of textile effluent using alum sludge and chitosan. Desalin. Water. Treat. 57 (16), 7280, 2016.
18. RAGHU S., BASHA C.A. Chemical or electrochemical techniques, followed by ion exchange, for recycle of textile dye wastewater. J. Hazard. Mater. 149 (2), 324, 2007.

19. BUTLER E. B., HUNG Y. T., MULAMBA O. The effects of chemical coagulants on the decolorization of dyes by electrocoagulation using response surface methodology (RSM). App. Water Sci. 1, 2016.

20. LIN S.H., PENG C.F. Continuous treatment of textile wastewater by combined coagulation, electrochemical oxidation and activated sludge, Water Res., 30, 587, 1996.

21. ONCEL M.S., MUHCU A., DEMIRBAS E., KOBYA M. A comparative study of chemical precipitation and electrocoagulation for treatment of coal acid drainage wastewater. J. Environ. Chem. Eng., 1 (4), 989, 2013.

22. ALI A., SHAIKH I.A., ABID T., QAYYUM S., KHALID A., NAVEED N., SAMINA F. ZAMEER M. Application of chitosan in the recycling of spent wash-off liquor from cotton dyeing. Sci Int. (Lahore), 28 (2), 1213, 2016.

23. DANESHVAR N., OLADEGARAGOZE A., DJAFARZADEH N. Decolorization of basic dye solutions by electrocoagulation: an investigation of the effect of operational parameters. J. Hazard. Mater. 129 (1), 116, 2006.

24. WANG H., TANG Z., ZHOU W. A method for dyeing cotton fabric with anthocyanin dyes extracted from mulberry (Morus rubra) fruits. Coloration Technology, 132 (3), 222, 2016.

25. YOUNG K.W., WHITTLE K.J. Colour measurement of fish minces using Hunter L, a, b values. J. Sci. Food Agric. 36 (5), 383, 1985.

26. RODRIGUEZ J.D., COMSTOCK M., AUZ B., OLMSTEAD T. A spectroscopic method of determining color of petroleum products using CIELab color space with LED illumination. InPhotonic Instrument. Eng. IV (Vol. 10110, pp. 101101L-1), 2017.

27. MOLLAH M.Y., PATHAK S.R., PATIL P.K., VAYUVEGULA M., AGRAWAL T.S., GOMES J.A., KESMEZ M. COCKE D.L. Treatment of orange II azodye by electrocoagulation (EC) technique in a continuous flow cell using sacrificial iron electrodes. J. Hazard. Mater. 109 (1), 165, 2004.

28. MOHAN D., PITTMAN C.U. Arsenic removal from water/wastewater using adsorbents - a critical review. J. Hazard. Mater. 142 (1), 1, 2007.

29. MENON D., CALVAGNO G. Color image demosaicking: An overview. Signal Processing: Image Communication. $26(8), 518,2011$.

30. IFTIKHAR M., JAMIL N.A., SHAHBAZ B. Rubbing, Ironing and Dry Cleaning Fastness of Reactive Dyed Cotton Knitted Fabric as Influenced by Salt, Alkali and Dye. Int. J. Agric. Biol. 3, 109, 2011.

31. PUVANESWARI N., MUTHUKRISHNAN J., GUNASEKARAN P. Toxicity assessment and microbial degradation of azo dyes. Ind. J. Exp. Biol. 44, 618, 2006. 